\title{
Abundance of non-target pests in transgenic Bt-maize: A farm scale study
}

\author{
XAVIer PONS, BelÉN LUMBIERRES, CARMEN LÓPEZ and RAMON ALBAJES
}

Universitat de Lleida, Centre UdL-IRTA, Rovira Roure 191, 25198 Lleida, Spain; e-mail: xavier.pons@irta.es

Key words. Bt-maize, non-target species, aphids, leafhoppers, cutworms, wireworms

\begin{abstract}
The impact of transgenic Bt-maize, expressing the Cry1Ab protein, on aphids, leafhoppers, cutworms and wireworms was evaluated at the farm scale by comparing their abundance on Bt-plots and those sown with the isogenic variety over three consecutive growing seasons. The impact of Bt-maize was different on each of the three-herbivore groups. There were significantly more aphids on the Bt-maize but in terms of aphid species, the difference was only statistically significant for Sitobion avenae and not for the other three most abundant species (Metopolophium dirhodum, Rhopalosiphum padi and Macrosiphum euphorbiae). The analysis of aphid age structure showed consistently more individuals on Bt-plots; differences were significant for alates, apterous adults and young nymphs of $R$. padi, apterous adults and apterous fourth instar nymphs of $S$. avenae, alates, apterous adults and apterous fourth instar nymphs of $M$. dirhodum. Leafhoppers (Zyginidia scutellaris), particularly mature nymphs, were also more abundant on the Btmaize. In spite of this there was no difference in leafhopper damage to $\mathrm{Bt}$ and non Bt-maize. The reasons for this are unclear but may be due to changes in Bt-maize that favoured aphids and leafhoppers. Differences in aphid and leafhopper densities were not high enough to affect yield. However, they may have affected the availability of prey for polyphagous predators such as Orius sp. The Btmaize did not affect the incidence of cutworms (Agrotis segetum) or wireworms (Agriotes lineatus). These results indicate that Btmaize does not have a negative impact on the non-target maize biocenosis at the farm scale.
\end{abstract}

\section{INTRODUCTION}

Transgenesis of maize with a gene expressing the $\delta$-endotoxin Cry1Ab from Bacillus thuringiensis Berliner var. kurstaki (Bt-maize) is a new approach to the control of maize corn borers. It may be compatible with other control methods but more information is needed before it can be incorporated into current IPM programmes. An assessment of the ecological effects of Bt maize on components of the maize biocenosis other than corn borers, is essential.

Cryl $\mathrm{Ab}$ toxin is considered to be very selective in its action and the impact of Bt maize on non-target arthropods is therefore expected to be minimal. However, the continuous production of toxins by some plant tissues throughout the growing season results in a level of exposure that did no occur with traditional insecticides based on B. thuringiensis. Furthermore, there may be some unintended side effects of genetically engineered Btmaize.

There are now many studies on the effects of Bt-maize on the natural enemies of maize pests. Most reports indicate no negative effects on predators in the field (Pilcher et al., 1997; Bourguet et al., 2002; Musser \& Shelton, 2003; De la Poza et al., 2005) or the laboratory (Orr \& Landis, 1997; Zwahlen et al., 2000; Al-Deeb et al., 2001; Dutton et al., 2002; Candolfi et al., 2004; Pons et al., 2004) except for the lacewing Chrysoperla carnea Stephens fed on lepidopterous larvae (Hilbeck, 1998; Dutton et al., 2002). However, Romeis et al. (2004) have recently reported that larvae of $C$. carnea are not sensitive to $\mathrm{Cry} 1 \mathrm{Ab}$ toxin and that the earlier reported negative effects of Bt-maize were prey-quality mediated rather than direct toxic effects. No negative effects on parasi- toids are reported (Orr \& Landis, 1997; Bourguet et al., 2002; Pons \& Starý, 2003; Manachini \& Lozzia, 2004).

There is far less literature dealing with the effects of Btmaize on non-target pests and most of these studies are on aphids. Laboratory investigations conclude that aphids cannot be affected because the toxin is not transported in the phloem sap on which the aphids feed (Head et al., 2001; Raps et al., 2001; Dutton et al., 2002). This may explain why no differences between aphid densities on $\mathrm{Bt}$ and non Bt-maize in the field are reported (Lozzia \& Rigamonti, 1998; Lozzia, 1999; Bourguet et al., 2002; Lumbierres et al., 2004). However, Lumbierres et al. (2004) found a significantly higher rate of offspring production by colonizing alate mothers of Rhopalosiphum padi $\mathrm{L}$. and consequently higher densities of this species on Bt transgenic maize commercially grown.

Bt-maize can potentially negatively affect population densities of non-target phytophagous insects due to the toxin. A positive effect due to the low level or absence of corn borers is also possible. Changes in nutritional quality due to unintended effects of the transgene can result in unpredictable effects. Direct effects of Bt-maize on the non-target pests can easily be measured in laboratory experiments. In contrast, the dynamic effects of the removal of other pests can only be measured in the field using large plots. Moreover, as Crawley (1999) stated, we need to study the effects of genetically modified crops on the demography of non-target species over their entire lifecycle and several generations in the field.

Most Bt-maize grown commercially in the European Union is in Spain (James, 2002), where 32,000 ha were grown in 2003, mostly in the NE of the Iberian Peninsula. Though six cultivars based on Event MON 810 and Syngenta Event 176 have been available since 2003, the most 
widely grown cultivar is still Compa $\mathrm{CB} \otimes$ (Event 176, Syngenta Seeds).

In the NE of the Iberian Peninsula aphids (several species), leafhoppers (Zyginidia scutellaris Herrich-Schäfer), cutworms (Agrotis segetum Denis \& Schiffemüller) and wireworms (Agriotes lineatus L.) are common maize pests, second only to the corn borers (Ostrinia nubilalis Hübner and Sesamia nonagrioides Lefèbvre) (Pons \& Albajes, 2002). The aim of this study was to determine the long term impact of Bt maize on these insects. This kind of research is lacking in Europe where field trials are restricted to small plots or short studies.

\section{MATERIAL AND METHODS}

\section{Characteristics of the experimental fields}

The study was conducted during the 2000, 2001 and 2002 maize growing seasons on a commercial farm located in Almenar (35 km west of Lleida, Catalonia, NE Iberian Peninsula) in an area where Bt-maize is grown regularly. For many years the farm crop rotation has been winter wheat (from December to June) and maize (from April to November); maize is therefore grown in the same plot in alternate years. Maize, wheat, alfalfa, canola and orchard trees were cultivated on the neighbouring farms.

Soil characteristics were: $\mathrm{pH}=7.8$, percentage organic matter $=3.1$ and percentage water at soil saturation $=32.0$. Crops were irrigated by flooding. The soil was prepared for sowing by the traditional method used in this region - subsoiling, ploughing to a depth of $15 \mathrm{~cm}$ with a disk harrow to incorporate fertiliser (based on pig and chicken manure), rolling and skim-ploughing with a rotary hoe (Piqué et al., 1998).

The experiments were carried out on 8 adjacent commercial plots each year according to the crop rotation of the farm, the set of plots used in 2000 being the same as in 2002. The experimental design consisted of four randomised blocks with two treatments: one plot sown with the transgenic cultivar (Compa $\mathrm{CB})$ and the other with the isogenic cultivar (Dracma ${ }^{\circledR}$, Syngenta Seeds). Both cultivars were sown on the same date (3 May 2000, 27 April 2001, and 30 March 2002). Two days after sowing, the plots were sprayed with a mixture of $35 \%$ alachlor + $25 \%$ atrazine, Primdal ${ }^{\circledR}$ (Agrodan. Braband, Denmark) at 4 1/ha, and with $75 \%$ isoxaflutol, Spade ${ }^{\circledR}$ (Bayer. Wuppertal, Germany), at $100 \mathrm{~g} / \mathrm{ha}$. No insecticide treatments were applied during the growth of the crop to avoid potential interference with the trial. Because commercial plots were used, the size varied from 0.4 to $1 \mathrm{ha}$, but was uniform within each block.

\section{Estimates of pest incidence}

The occurrence of pests was monitored from maize emergence until the beginning of maturity [Hanway's (1966) stage 9.1]. Sampling methods varied according to the pest. (1) Aphids: Aphid density was evaluated by visual counting on 10 to 25 plants per plot. Sampling dates were determined by the population dynamics of aphids in the area (Asín \& Pons, 2001). One sample was taken in May and two in June (in 2002 due to the earlier sowing, three samples were taken in May and only one in June), one during anthesis (mid-July), and two after anthesis (August and September). For each plant the number of aphids of each species was counted and the developmental stage was determined by distinguishing between alate and apterous adults, alatiform and apteriform fourth instar nymphs, and young nymphs (instars 1-3). (2) Leafhoppers: The occurrence of leafhoppers was monitored directly and indirectly twice per season, 10-15 days before and after anthesis. In the direct moni- toring one old green leaf (lower stratum), the cob leaf (middle stratum), and the youngest unfolded leaf (upper stratum) of 10 plants per plot were gently cut at the base, and each placed in a paper bag and brought to the lab where the bags were frozen. Later, the number of adults and nymphs were counted, distinguishing between young (instars 1-2, with red eyes and without wing buds) and mature nymphs (instars 3-5, with black eyes and wing buds). In the indirect monitoring the leafhopper damage to the leaves was measured. As Z. scutellaris is a mesophyll feeder, a SPAD-502® chlorophyll meter (Minolta Camera Co. Ltd., Osaka, Japan) was used to determine the damage caused by the leafhoppers. Ten SPAD measures were done on one leaf from the same three strata, as used in the direct counts (but from different plants), of 10 plants per plot. During sampling, the length and maximum width of each leaf measured with the SPAD were recorded and the leaf area was later calculated by multiplying length*width*0.743 (Stewart \& Dwyer, 1999). (3) A. segetum and A. lineatus: When plant emergence was complete, the number of plants in two rows of each plot (the $10^{\text {th }}$ from each edge) was recorded. The number of plants attacked in these rows was recorded weekly until plants were at the 11-leaf stage, after which there is no further attack (Piqué et al., 1998). Attacked plants were associated with a specific pest by the presence of its larva or the type of damage, and the final proportion of attacked plants was calculated.

\section{Maize yield}

Yield was recorded in each plot. The dates of harvest were 19 December 2000, 5 November 2001 and 5 November 2002. To compare yields between cultivars and years, the grain humidity at harvest was recorded and the yield was corrected to the standard humidity of $14 \%$.

\section{Statistical analysis}

A complete randomised block design with two cultivars (transgenic or conventional cultivar) and four replications (blocks) was used in the three consecutive years, in which the number of insects per plant, SPAD measurements, leaf area and grain yield were the dependent variables. For aphids, the sum of individuals counted for each species over the growing season was the variable used in the analysis. In the combined analyses of variance across years, a split-split-plot-like (number of leafhoppers, SPAD values and leaf area) or split-plot-like (aphids, wireworms, cutworms and yield) model (Gomez \& Gomez, 1984) was used. In the split-split-plot-like model, years were considered as main plots; subplots were the cultivar (transgenic

Table 1. ANOVA, $F$ and $P$ values for the single factors (year, and cultivar), the aphid species and total number of aphids. No significant values were found for double interactions.

\begin{tabular}{lcccc}
\hline \multirow{2}{*}{ Aphid species } & \multicolumn{2}{c}{ Year $^{(1)}$} & \multicolumn{2}{c}{ Cultivar $^{(2)}$} \\
\cline { 2 - 5 } & $F$ & $P$ & $F$ & $P$ \\
\hline R. padi & 8.16 & 0.02 & 2.05 & 0.20 \\
S. avenae & 108.67 & $<0.001$ & 8.11 & 0.03 \\
M. dirhodum & 271.20 & $<0.001$ & 4.36 & 0.08 \\
M. euphorbiae & 56.47 & $<0.001$ & 2.40 & 0.17 \\
S. graminum & 5.55 & 0.03 & 2.04 & 0.20 \\
S. maydis & 3.42 & 0.08 & 0.19 & 0.68 \\
Others & 3.51 & 0.07 & 0.29 & 0.61 \\
Total aphids & 135.90 & $<0.001$ & 6.00 & 0.05 \\
\hline
\end{tabular}

${ }^{(1)} \mathrm{df}=2,9 ;{ }^{(2)} \mathrm{df}=1,6$ 
TABLE 2. Mean values \pm SE of density (individuals/plant) of the different morphs (AL: alate adults; AP: apterous adults; $\mathrm{N}_{4} \mathrm{AL}$ : alatiform fourth instar nymphs; $\mathrm{N}_{4} \mathrm{AP}$ : apteriform fourth instar nymphs and $\mathrm{N}_{1-3}$ : first to third instar nymphs) of the four most abundant aphid species (R. padi + S.avenae $+M$. dirhodum + M. euphorbiae), and the total numbers of these four species on Bttransgenic and non-transgenic plants. Data before analysis were transformed using SQRT $(\mathrm{x}+0.5)$.

\begin{tabular}{|c|c|c|c|c|c|}
\hline \multirow{2}{*}{ Aphid species } & \multirow{2}{*}{ Morph } & \multicolumn{2}{|c|}{ Cultivar } & \multicolumn{2}{|c|}{ ANOVA values } \\
\hline & & Bt transgenic $(n=12)$ & Non transgenic $(\mathrm{n}=12)$ & $F$ & $P$ \\
\hline \multirow[t]{6}{*}{ R. padi } & $\mathrm{AL}$ & $3.33 \pm 0.85$ & $2.17 \pm 0.64$ & 18.1 & 0.005 \\
\hline & AP & $1.00 \pm 0.37$ & $0.43 \pm 0.14$ & 42.03 & $<0.001$ \\
\hline & $\mathrm{N}_{4} \mathrm{AL}$ & $1.27 \pm 1.25$ & $1.61 \pm 1.38$ & 0.05 & 0.82 \\
\hline & $\mathrm{N}_{4} \mathrm{AP}$ & $2.98 \pm 1.05$ & $2.52 \pm 1.44$ & 0.36 & 0.57 \\
\hline & $\mathrm{N}_{1-3}$ & $14.71 \pm 3.99$ & $9.35 \pm 3.10$ & 5.89 & 0.05 \\
\hline & Total & $23.28 \pm 5.36$ & $16.08 \pm 4.73$ & 2.05 & 0.20 \\
\hline \multirow[t]{6}{*}{ S.avenae } & $\mathrm{AL}$ & $1.10 \pm 0.44$ & $1.11 \pm 0.44$ & 0.30 & 0.61 \\
\hline & AP & $1.84 \pm 0.47$ & $0.84 \pm 0.25$ & 11.37 & 0.02 \\
\hline & $\mathrm{N}_{4} \mathrm{AL}$ & $6.48 \pm 4.44$ & $3.60 \pm 2.48$ & 0.41 & 0.54 \\
\hline & $\mathrm{N}_{4} \mathrm{AP}$ & $4.58 \pm 1.33$ & $2.53 \pm 1.03$ & 20.27 & 0.004 \\
\hline & $\mathrm{N}_{1-3}$ & $24.27 \pm 7.38$ & $18.49 \pm 6.44$ & 5.25 & 0.06 \\
\hline & Total & $38.27 \pm 9.66$ & $26.42 \pm 8.15$ & 8.11 & 0.03 \\
\hline \multirow[t]{6}{*}{ M. dirhodum } & $\mathrm{AL}$ & $6.99 \pm 2.72$ & $4.64 \pm 1.83$ & 12.15 & 0.01 \\
\hline & $\mathrm{AP}$ & $2.88 \pm 1.21$ & $1.36 \pm 0.69$ & 12.03 & 0.01 \\
\hline & $\mathrm{N}_{4} \mathrm{AL}$ & $4.28 \pm 1.85$ & $3.95 \pm 2.01$ & 0.94 & 0.37 \\
\hline & $\mathrm{N}_{4} \mathrm{AP}$ & $15.19 \pm 6.90$ & $11.81 \pm 5.86$ & 36.00 & 0.001 \\
\hline & $\mathrm{N}_{1-3}$ & $170.80 \pm 70.83$ & $147.98 \pm 64.91$ & 3.2 & 0.13 \\
\hline & Total & $200.14 \pm 82.53$ & $169.74 \pm 74.72$ & 4.36 & 0.08 \\
\hline \multirow[t]{6}{*}{ M. euphorbiae } & $\mathrm{AL}$ & $1.16 \pm 0.49$ & $0.89 \pm 0.42$ & 3.5 & 0.11 \\
\hline & $\mathrm{AP}$ & $2.20 \pm 0.94$ & $1.96 \pm 0.96$ & 1.16 & 0.32 \\
\hline & $\mathrm{N}_{4} \mathrm{AL}$ & $1.06 \pm 0.54$ & $0.66 \pm 0.50$ & 1.57 & 0.26 \\
\hline & $\mathrm{N}_{4} \mathrm{AP}$ & $5.63 \pm 2.41$ & $6.36 \pm 3.26$ & 0.14 & 0.72 \\
\hline & $\mathrm{N}_{1-3}$ & $26.20 \pm 11.04$ & $23.14 \pm 11.71$ & 2.56 & 0.16 \\
\hline & Total & $36.25 \pm 15.15$ & $33.01 \pm 16.74$ & 2.40 & 0.17 \\
\hline \multirow[t]{6}{*}{ Sum of 4 species } & $\mathrm{AL}$ & $12.58 \pm 3.59$ & $8.64 \pm 2.48$ & 26.97 & 0.002 \\
\hline & AP & $7.92 \pm 2.75$ & $4.59 \pm 1.93$ & 13.85 & 0.01 \\
\hline & $\mathrm{N}_{4} \mathrm{AL}$ & $13.09 \pm 4.45$ & $9.82 \pm 3.58$ & 2.77 & 0.15 \\
\hline & $\mathrm{N}_{4} \mathrm{AP}$ & $28.38 \pm 11.17$ & $23.22 \pm 10.87$ & 11.30 & 0.02 \\
\hline & $\mathrm{N}_{1-3}$ & $235.98 \pm 91.57$ & $198.97 \pm 84.32$ & 4.16 & 0.09 \\
\hline & Total & $297.95 \pm 109.32$ & $245.25 \pm 100.95$ & 6.26 & 0.05 \\
\hline Total aphids & & $298.47 \pm 109.41$ & $245.72 \pm 100.94$ & 6.00 & 0.05 \\
\hline
\end{tabular}

vs. non transgenic) and leaf stratum (lower, middle, upper); subsubplots were the sampling dates, whereas in the split-plot-like model, years were considered as main plots and the subplots were the cultivar. All factors except blocks were considered as fixed terms. The error term for year effect was block(year) and the subplot error was cultivar*leaf stratum*block(year) in the leafhopper analysis. To normalize the original data, variables were transformed by SQRT $(\mathrm{x}+0.5)$ (insects/plant) or $\operatorname{ASIN}[\operatorname{SQRT}(\mathrm{x} / 100)]$ (percentages of plants attacked) prior to analysis. The LSD test was used to compare means of significant factors. All data were analysed using the Statgraphics package (Statgraphic, 1997).

\section{RESULTS}

\section{Aphids}

Several aphid species were recorded on the maize plants: Rhopalosiphum padi Linnaeus, Sitobion avenae Fabricius, Metopolophium dirhodum Walker, Macrosiphum euphorbiae Thomas, Sipha maydis Passerini, Schizaphis graminum Rondani, Aphis gossypii Glover, Aphis fabae Scopoli and Hyalopterus amygdali (E. Blanchard). There were no differences in aphid species composition between Bt-transgenic and non-transgenic plots. Metopolophium dirhodum, R. padi, S. avenae and M. euphor- 
TABle 3. ANOVA, $F$ and $P$ values for the single factors (year, cultivar, leaf stratum and sampling date) for (a) the leafhopper $Z$. scutellaris populations (direct counts): total leafhoppers, adults, mature nymphs (N3-N5 instars) and young nymphs (N1 and N2 instars) and (b) two plant indicators of potential damage, the SPAD values and leaf area (indirect evidence). Data of direct counts were transformed using SQRT $(\mathrm{x}+0.5)$.

\begin{tabular}{|c|c|c|c|c|c|c|c|c|}
\hline & \multicolumn{2}{|c|}{ Year $^{(1)}$} & \multicolumn{2}{|c|}{ Cultivar $^{(2)}$} & \multicolumn{2}{|c|}{ Leaf-stratum ${ }^{(3)}$} & \multicolumn{2}{|c|}{ Sampling date ${ }^{(4)}$} \\
\hline & $F$ & $P$ & $F$ & $P$ & $F$ & $P$ & $F$ & $P$ \\
\hline \multicolumn{9}{|l|}{ (a) direct counts } \\
\hline Total & 73.53 & $<0.001$ & 4.66 & 0.04 & 571.66 & $<0.001$ & 13.13 & 0.004 \\
\hline Adults & 38.12 & $<0.001$ & 1.48 & 0.23 & 225.45 & $<0.001$ & 0.04 & 0.85 \\
\hline Mature nymphs & 36.29 & $<0.001$ & 5.01 & 0.03 & 452.17 & $<0.001$ & 24.52 & $<0.001$ \\
\hline Young nymphs & 20.30 & $<0.001$ & 0.35 & 0.56 & 129.53 & $<0.001$ & 10.79 & 0.007 \\
\hline \multicolumn{9}{|c|}{ (a) indirect evidence } \\
\hline SPAD & 73.94 & $<0.001$ & 0.032 & 0.86 & 207.86 & $<0.001$ & 63.31 & $<0.001$ \\
\hline Leaf area & 65.48 & $<0.001$ & 2.68 & 0.11 & 4.82 & $<0.001$ & 4.82 & $<0.05$ \\
\hline
\end{tabular}

biae were the four most abundant species on both cultivars.

ANOVA showed a significant effect of the main factors, year and cultivar (Table 1). No double interaction between cultivar and year was found.

Significant differences due to the year occurred for the total aphids and for each of the species present, except for S. maydis. The occurrence of aphids was higher in 2002 than in 2000 and 2001. Also, the seasonal abundance and the relative abundance of the aphid species varied between years.

Cultivar affected the total number of aphids, which was significantly higher on the Bt-transgenic cultivar. But when the main species were considered only $S$. avenae showed significantly higher numbers on the Bt cultivar. The influence of the cultivar was analysed for each developmental stage of the four most abundant species and the results are shown in Table 2. Aphid densities were consistently higher in Bt plots for all species and ages (except in three out of the 25 species and age combinations), and in 11 cases the differences were statistically significant $(P<$ 0.05 ). Whereas $M$. euphorbiae abundance was not different on the two cultivars for any of the developmental stages, the adults (alate and apterous) and young nymphs

TABLE 4. Mean values $\pm \mathrm{SE}$ of the density (individuals/plant) of the leafhopper Z. scutellaris [(total, adults, mature nymphs (N3-N5 instars) and young nymphs (N1-N2 instars)] and mean \pm SE of the SPAD measures and leaf area $\left(\mathrm{cm}^{2}\right)$ of Bttransgenic and non-transgenic plants. Means are compared within each row. Values followed by different letters are significantly different $(P<0.05)$.

\begin{tabular}{lcc}
\hline & $\begin{array}{c}\text { Bt-transgenic } \\
(\mathrm{n}=72)\end{array}$ & $\begin{array}{c}\text { Non-transgenic } \\
(\mathrm{n}=72)\end{array}$ \\
\hline Total leafhoppers & $13.46 \pm 2.31 \mathrm{a}$ & $11.59 \pm 2.22 \mathrm{~b}$ \\
Adults & $1.74 \pm 0.27$ & $1.54 \pm 0.27$ \\
Mature nymphs (N3-N5) & $9.89 \pm 1.81 \mathrm{a}$ & $8.23 \pm 1.64 \mathrm{~b}$ \\
Young nymphs (N1-N2) & $1.82 \pm 0.36$ & $1.82 \pm 0.49$ \\
SPAD & $46.24 \pm 1.44$ & $46.21 \pm 1.55$ \\
Leaf area & $403.57 \pm 19.03$ & $393.21 \pm 18.66$ \\
\hline
\end{tabular}

of $R$. padi, the apterous adults and the apteriform fourth instar nymphs of $S$. avenae and adults (alate and apterous) and the apteriform fourth instar nymphs of $M$. dirhodum were significantly more abundant on the transgenic cultivar.

\section{Leafhoppers}

Zyginidia scutellaris was the most abundant species in the three year-study and accounted for nearly all the leafhoppers recorded. Other unidentified leafhopper species were rarely observed.

The main effects (year, leaf stratum and sampling date) were significant in the ANOVA performed for the most variables directly or indirectly related to leafhoppers (Table 3). No double or triple interactions between cultivar and year, leaf stratum and sampling date were found. The leafhopper population varied every year and the highest populations occurred in 2000, followed by 2001 and 2002. The lower leaves consistently supported more leafhoppers than the middle leaves, which had similar numbers to the upper leaves.

The cultivar had a significant effect on total number of leafhoppers or mature nymphs; the density in Bttransgenic plots was higher than in non-transgenic, but no cultivar effects were detected on the other developmental stages (Tables 3 and 4). Leaf area and SPAD were not affected by cultivar.

\section{Soil pests}

No other species than the cutworm $A$. segetum and the wireworm $A$. lineatus were recorded. The results of the ANOVA for the main factors are shown in Table 5. No effects of cultivar on the percentage of plants killed by soil worms were found. This was the case for cutworms and wireworms, and the two combined (Table 5).

\section{Maize yield}

Results of the ANOVA show that there was a significant effect of year $(F=4.97 ; P=0.04, \mathrm{df}=2,9)$ and cultivar $(F=12.26, P=0.01 ; \mathrm{df}=1,6)$ but not of the double interaction year*cultivar $(F=2.28 ; P=0.18$; df $=2,6)$. The yield was lower in 2002 than in 2000 and 2001. The 
Table 5. ANOVA, $F$ and $P$ values for the single factors (year and cultivar) of the percentage of plants killed by cutworms and wireworms.

\begin{tabular}{lcccccc}
\hline \multirow{2}{*}{ Soil pest species } & \multicolumn{3}{c}{ Year $^{(1)}$} & \multicolumn{2}{c}{ Cultivar $^{(2)}$} & \% attack \\
\cline { 2 - 5 } & $F$ & $P$ & $F$ & $P$ & (mean $\pm \mathrm{se}$ ) \\
\hline Cutworms (A. segetum) & 12.80 & 0.002 & 0.15 & 0.71 & $0.26 \pm 0.04$ \\
Wireworms (A. lineatus) & 4.60 & 0.04 & 0.17 & 0.69 & $2.21 \pm 0.97$ \\
Total soil pests & 4.17 & 0.05 & 0.23 & 0.65 & $2.48 \pm 0.96$ \\
\hline${ }^{(1)} \mathrm{df}=2,9 ;{ }^{(2)} \mathrm{df}=1,6$ & & & & &
\end{tabular}

mean yield of the three years was significantly higher $(P$ $<0.05)$ in Bt plots $(10738 \pm 299 \mathrm{~kg} / \mathrm{ha})$ than in non-Bt $(10169 \pm 349 \mathrm{~kg} / \mathrm{ha})$.

\section{DISCUSSION}

One of the primary ecological concerns of growing $\mathrm{Bt}$ plants is the possible effect it may have on the non-target organisms (Conner et al., 2003). The commercial introduction of Bt-maize in Spain prompted a monitoring programme funded by the Spanish Government to enable a science-based discussion of the risks and benefits of using Bt-maize. One part of this programme evaluated at the farm scale the potential risks of Bt-maize to predators (De la Poza et al., 2005). Another part was on the impact on non-target pests and is presented here.

The transgenic cultivar tested in the present work, Compa $\mathrm{CB}$, is derived from event 176 that causes expression of $B$. thuringiensis $\mathrm{Cry} 1 \mathrm{Ab}$ in the green tissues and pollen. The toxin is active against some Lepidoptera but not for non-Lepidopteran herbivores. Among the maize pests monitored in this work, cutworms (Lepidoptera: Noctuidae) were the only phytophagous species that could be potentially affected by the ingestion of transgenic maize green tissues.

The results show that the total numbers of the most abundant aphid species, except $S$. avenae, were similar on control and Bt-maize. Similar results were found by Bourguet et al. (2002) in a one-year study in the South of France using a maize cultivar containing event MON 810 . However, our experiments indicate that the transgenic maize did affect some developmental stages of aphid species as the density of these stages on Bt-maize was always higher. This phenomenon was mainly recorded for $R$. padi, in which the density of alate and apterous adults and young nymphs was higher on Bt plants. These results agree with those of Lumbierres et al. (2004) who found a higher density of $R$. padi alates and young nymphs on $\mathrm{Bt}$ plants during aphid colonization, and a higher intrinsic rate of natural increase of the offspring of alates feeding on Bt-maize. Significant differences between cultivars in the numbers of some aphid developmental stages were also found for two of the other main aphid species $(S$. avenae and $M$. dirhodum) for which there are no previous records in the literature. This suggests that the higher abundance of aphids on Bt-transgenic maize is not the consequence of the response of a particularly abundant aphid species to the transgenic cultivar but of the cumulated effect of the higher, although sometimes statististi- cally non-significant, abundances of the four main aphid species on the Bt cultivar. It is difficult to assign causes for the greater abundance of aphids on Bt plants, as the Bt-toxin is not transported in the phloem (Head et al., 2001; Raps et al., 2001; Dutton et al., 2002). Lumbierres et al. (2004) suggest that pleiotropic effects (visual or olfactory cues, or changes in physical characteristics) may make Bt plants more attractive for $R$. padi and account for the higher abundance during alate settlement and reproduction, although this hypothesis needs to be tested. Moreover, differences could be also due to varietal differences caused by the breeding procedures, which are impossible to differentiate from the pleiotropic effects. Lumbierres et al. (2004) also observed that after aphid colonization, there were no significant difference in the numbers of $R$. padi on $\mathrm{Bt}$ and non-Bt plants. Therefore, it can be assumed that the greater number of alates colonizing a Bt-maize and their subsequent reproduction determine the difference in the aphid population densities throughout the rest of the season, because transgenic plants do not affect aphid numbers after colonization.

The leafhopper Z. scutellaris feeds on the contents of mesophyll cells of maize (Marion-Poll et al., 1987) and may ingest the Bt-toxin from $\mathrm{Bt}$ transgenic plants because it is present in mesophyll cells. However, Dutton et al. (2004) detected, using ELISA, only small quantities of toxin in Z. scutellaris that had fed on Bt-maize Event Bt11, which contains a higher concentration of toxin than Event Syngenta 176 (Dutton et al., 2003). A similar result was observed by Obrist (pers. commun.), who took occasional samples of leafhopper adults from our experimental fields and using ELISA detected an amount of $\mathrm{Cry} 1 \mathrm{Ab}$ much lower than that found in spider mites fed on the same plants. Rauschen et al. (2004) did not find a significant difference between leafhopper abundance on transgenic Bt-maize (Event MON 810) and the isogenic variety. In contrast, in our experiment similar results to those for aphids occurred with a higher abundance of $Z$. scutellaris on Bt-maize, particularly mature nymphs. The reasons for this could be changes in Bt-maize that favoured the leafhopper. The differences between our results and those of Rauschen et al. (2004) could be due to a different response of the local leafhopper population to transgenic maize. However, there was no statistical difference in the damage done to the two cultivars in spite of the different densities of leafhopper.

Cutworms and wireworms live in the soil and eat maize plants. In the western Mediterranean region, both chew the base of plant stems, and A. lineatus also feeds on seeds and roots. Consequently, they may ingest Bt-toxin as noted by Dutton et al. (2004). However, we found no significant difference in the incidence of $A$. lineatus and A. segetum in $\mathrm{Bt}$ and non-Bt plots. One reason for this, in the case of A. segetum, could be the low level of Bt-toxin in the roots and stems of Event Syngenta 176 (Dutton et al., 2003), from which the cultivar Compa used in our trial was derived. Other authors have noted that Bt-maize does not provide a good control of some noctuid moths, including A. ipsilon (Andow, 2002). 
In spite of the statistical difference in aphid and leafhopper abundance on Bt and non-Bt plants, the differences in abundance on the two cultivars were probably insufficient to have economic consequences. This is evident as the estimates of leafhopper damage to the two cultivars (i.e. SPAD measure) did not differ significantly. Furthermore, the yield of Bt-maize was higher, probably due to the effectiveness of this cultivar against corn borers, and that the higher densities of aphids and leafhoppers did not affect yield. On this point, our results agree with other field studies that show no effect of Bt-maize on non-target phytophagous insects (Lozzia \& Rigamonti, 1998; Bourguet, 2002; Candolfi et al., 2004; Rauschen et al., 2004; Sehnal et al., 2004).

However, the higher numbers of aphids and leafhoppers on Bt-plots can lead to a greater prey availability for polyphagous predators, which are abundant on maize plants in the region (Albajes et al., 2003) and may explain the higher occurrence of Orius sp. on Bt plots recorded by several authors and ourselves (Jasinski et al., 2003; Musser \& Shelton, 2003; De la Poza et al., 2005).

In conclusion, aphids and leafhoppers were more abundant on Bt-maize but their higher densities do not result in economic losses and may become an important prey resource for predators. Wireworms and cutworms were not affected by Bt-maize. These results, together with those dealing with the effects on the predatory fauna (De la Poza, 2005) suggest that Bt-maize does not have a negative impact on the non-target maize biocenosis. However, studies at the landscape scale should be conducted in order to assess risks over longer periods.

ACKNOWLEDGEMENTS. This research was funded by the Spanish Government (Ministry of Science and Technology (MCYT)), project number AGF99-0782. Thanks are due to I. Romagosa, from the University of Lleida and J. Comas from the Politechnics University of Catalonia for assistance with the statistical analysis. We further thank two anonymous referees for their critical comments on a previous draft of this manuscript.

\section{REFERENCES}

Albajes R., López C. \& Pons X. 2003: Predatory fauna in corn fields and response to imidacloprid seed treatment. J. Econ. Entomol. 96: 1805-1813.

Al-Deeb M.A., Wilde G.E. \& Higgins R.A. 2001: No effect of Bacillus thuringiensis corn and Bacillus thuringiensis on the predator Orius insidiosus (Hemiptera: Anthocoridae). Environ. Entomol. 30: 625-629.

ANDow D.A. 2002: Resisting resistance to Bt-corn. In Letourneau D.K. \& Burrows B.E. (eds): Genetically Modified Organisms. Assessing Environmental and Human Health Effects. CRC Press, Boca Raton, pp. 99-124.

Asín L. \& Pons X. 2001: Effect of high temperature on the growth and reproduction of corn aphids (Homoptera: Aphididae) and implications for their population dynamics on the northeastern Iberian Peninsula. Environ. Entomol. 30: 1127-1134.

Bourguet D., Chaufaux J., Micoud A., Delos M., Naïbo B., Bombarde F., Marque G., Eychenne N. \& Pagliari C. 2002: Ostrinia nubilalis parasitism and the field abundance of nontarget insects in transgenic Bacillus thuringiensis corn (Zea mays). Environ. Biosafety Res. 1: 49-60.
Candolfi M.P., Brown K., Grimm C., Reber B. \& Schmidli H. 2004: A faunistic approach to assess potential side-effects of genetically modified Bt-corn on non-target arthropods under field conditions. Biocontrol Sci. Techn. 14: 129-170.

Conner A.J., Glare T.R. \& NAP J.-P. 2003: The release of genetically modified crops into the environment. Part II: Overview of ecological risk assessment. Plant J. 33: 19-46.

Crawley M.J. 1999: Bollworms, genes, and ecologists. Nature 400: $501-502$.

De la Poza M., Pons X., Farinós G.P., López C., Ortego F., Eizaguirre M., Castañera P. \& Albajes R. 2005: Impact of farm scale Bt maize on predatory fauna in Spain. Crop Prot. (in press).

Dutton A., Klein H., Romeis J. \& Bigler F. 2002: Uptake of Bttoxin by herbivores feeding on transgenic maize and consequences for predator Chrysoperla carnea. Ecol. Entomol. 27: 441-447.

Dutton A., Romeis J. \& Bigler F. 2003: Assessing the risks of insect resistant transgenic plants on entomophagous arthropods: Bt-maize expressing Cry1 Ab as a case study. BioControl 48: 611-636.

Dutton A., Obrist L., D’Alessandro M., Diener L., Müller M., Romeis J. \& Bigler F. 2004: Tracking Bt-toxin in transgenic maize to assess the risks on non-target arthropods. IOBC/WPRS Bull. 27(3): 57-64.

Gomez K.A. \& Gomez A.A. 1984: Statistical Procedures for Agricultural Research. 2nd ed. Wiley, New York, pp. 680.

Hanway J.J. 1966: How a Corn Plant Develops. Special Report No. 48. Iowa State University of Science and Technology Cooperative Extension Services, Ames, Iowa, 17 pp.

Head G., Brown C.R., Groth M. \& Duan J.J. 2001: Cry1Ab protein levels in phytophagous insects feeding on transgenic corn: implications for secondary exposure risk assessment. Entomol. Exp. Appl. 99: 37-45.

Hilbeck A., Baumgartner M., Fried M.F. \& Bigler F. 1998: Effects of transgenic Bacillus thuringiensis corn-fed prey on mortality and development time of immature Chrysoperla carnea (Neuroptera: Chrysopidae). Environ. Entomol. 27: 480-487.

JAMES C. 2002: Global Status of Commercialized Transgenic Crops: 2002. Preview. ISAAA briefs No. 27. International Service for the Acquisition of Agri-Biotec Applications, Ithaca, NY, 36 pp.

Jasinski J.R., Eisley J.B., Young C.E., Kovach J. \& Willson H. 2003: Select nontarget arthropod abundance in transgenic and nontransgenic field crops in Ohio. Environ. Entomol. 32: 407-413.

LozzIA G.C. 1999: Biodiversity and structure of ground beetle assemblages (Coleoptera: Carabidae) in Bt corn and its effects on non target insects. Boll. Zool. Agr. Bachic (Ser. II) 31: $37-58$.

Lozzia G.C. \& Rigamonti I.E. 1998: Preliminary study on the effects of transgenic maize on non target species. IOBC/WPRS Bull. 21(8): 171-180.

Lumbierres B., Albajes R. \& Pons X. 2004: Transgenic Btmaize and Rhopalosiphum padi (Hom., Aphididae) performance. Ecol. Entomol. 29: 309-317.

Manachini B. \& Lozzia G.C. 2004: Studies on the effects of Bt corn expressing Cry1 Ab on two parasitoids of Ostrinia nubilalis Hb. (Lepidoptera Crambidae). IOBC/WPRS Bull. 27(3): 109-116.

Marion-Poll F., Della Giustina W. \& Mauchamp B. 1987: Changes of electric patterns related to feeding in a mesophyl feeding leafhopper Zyginidia scutellaris. Entomol. Exp. Appl. 43: $115-124$ 
Musser F.R. \& Shelton A.M. 2003: Bt sweet corn and selective insecticides: impacts on pests and predators. J. Econ. Entomol. 96: 71-80.

ORR D.B. \& LANDIS D.A. 1997: Oviposition of European corn borer (Lepidoptera: Pyralidae) and impact of natural enemy populations in transgenic versus isogenic corn. J. Econ. Entomol. 90: 905-909.

Pilcher C.D., Obrycki J.J., Rice M.E. \& Lewis L.C. 1997: Preimaginal development, survival, and field abundance of insect predators on transgenic Bacillus thuringiensis corn. Environ Entomol. 26: 446-454.

Piqué J., Eizaguirre M. \& Pons X. 1998: Soil insecticide treatments against maize soil pests and corn borers in Catalonia under traditional crop conditions. Crop Prot. 17: 557-561.

Pons X. \& Albajes R. 2002: Control of maize pests with imidacloprid seed dressing treatment in Catalonia (NE Iberian Peninsula) under traditional crop conditions. Crop Prot. 21: 943-950.

Pons X. \& Starý P. 2003: Spring aphid-parasitoid (Hom., Aphididae, Hym., Braconidae) associations and interactions in a Mediterranean arable crop ecosystem, including $\mathrm{Bt}$ maize. J. Pest Sci. 76: 133-138.

Pons X., Lumbierres B., López C. \& Albajes R. 2004: No effects of Bt maize on the development of Orius majusculus. IOBC/WPRS Bull. 27(3): 131-136.
Raps A., Kehr J., Gugerli P., Moar W.J., Bigler F. \& Hilbeck A. 2001: Immunological analysis of phloem sap of Bacillus thuringiensis corn and of the nontarget herbivore Rhopalosiphum padi (Homoptera: Aphididae) for the presence of Cry1Ab. Mol. Ecol. 10: 525-533.

Rauschen S., Ecker J., Gathmann A. \& Schuphan I. 2004: Impact of growing Bt-maize on cicadas: Diversity, abundance and methods. IOBC/WPRS Bull. 27(3): 137-142.

Romeis J., Dutton A. \& Bigler F. 2004: Bacillus thuringiensis toxin $(\mathrm{Cry} 1 \mathrm{Ab})$ has no direct effect on larvae of the green lacewing Chrysoperla carnea (Stephens) (Neuroptera: Chrysopidae). J. Insect Physiol. 50: 175-183.

Sehnal F., Habuštová O., Spitzer L., Hussein H.M. \& RŮžžčKa V. 2004: A biannual study on the environmental impact of Bt maize. IOBC/WPRS Bull. 27(3): 147-160.

Statgraphics 1997: Statgraphics Plus, Version 3. Manugistics, Inc. Rockville, MD, pp. 749.

Stewart D.W. \& Dwyer L.M. 1999: Mathematical characterization of leaf shape and area of maize hybrids. Crop Sci. 39: 422-427.

Zwahlen C., Nentwig W., Bigler F. \& Hilbeck A. 2000: Tritrophic interactions of transgenic Bacillus thuringiensis corn, Anaphothrips obscurus (Thysanoptera: Thripidae), and the predator Orius majusculus (Heteroptera: Anthocoridae). Environ. Entomol. 29: 846-850.

Received April 21, 2004; revised August 8, 2004; accepted September 27, 2004 